\title{
Tracking the oxygen isotopic signature from the rainfall to the speleothems in Ortigosa de Cameros caves (La Rioja, Spain)
}

\section{Trazabilidad de la señal isotópica del oxígeno desde la lluvia a los espeleotemas en las cuevas de Ortigosa de Cameros (La Rioja, España)}

\author{
M.C. Osácar ${ }^{1}$, C. Sancho ${ }^{1}$, A. Muñoz 1 , M. Bartolomé ${ }^{2}$, A. Moreno², \\ A. Delgado-Huertas ${ }^{3}$, I. Cacho ${ }^{4}$ \\ 1 Dpto. de Ciencias de la Tierra, Universidad de Zaragoza, C/Pedro Cerbuna 12, 50009 Zaragoza. Email: cinta@unizar.es \\ 2 Instituto Pirenaico de Ecología, CSIC, Avda. de Montañana 1005, 50059 Zaragoza \\ 3 Instituto Andaluz de Ciencias de la Tierra, CSIC, Avda. de Las Palmeras 4, 18100 Armilla, Granada \\ 4 Departament d'Estratigrafia, Paleontologia i Geociències Marines, Universitat de Barcelona, C/Marti i Franquès s/n, 28080 \\ Barcelona
}

\begin{abstract}
A one-year monitoring survey has been carried out in La Paz and La Viña Caves in the Ortigosa de Cameros Cave System (NE Iberian Peninsula), in order to track the oxygen isotope signal from rainfall to speleothem calcite, assessing the ability of this signal to retain environmental information. Oxygen isotope signals of rainfall events, drip water - sampled every three months-, and speleothem calcite, precipitated over three-months, are compared. Water dripping follows precipitation events in winter, spring and summer, more closely in the near-surface drip points than in the deeper ones. In autumn, dripping is delayed with respect to rainfall, suggesting that water stays in the epikarst before dripping resumes after summer. This delay causes a deviation of the total drip water signal (average $\delta^{18} \mathrm{O}=-8.39 \%$ V-SMOW) from the rainfall signal (average $\delta^{18} \mathrm{O}=-7.41 \% \mathrm{~V}-\mathrm{SMOW}$ ). On the contrary, in winter the isotopic signal of drip water keeps the rainfall signal. Calcite isotopic signal (total average $\delta^{18} \mathrm{O}=-6.83 \%$ o V-PDB) shows a small offset $(0.62-0.75 \%)$ with respect to the signal predicted by drip water oxygen composition; this points to a limited kinetic effect in calcite precipitation, therefore calcite retains the signal of rainfall, especially in winter.
\end{abstract}

Keywords: oxygen isotope signal; speleothem calcite; cave monitoring; Northern Iberia.

\section{RESUMEN}

Durante un año se han monitorizado las cuevas de La Paz y La Viña en el Sistema de Cuevas de Ortigosa de Cameros (NE de la Península Ibérica) para rastrear la señal isotópica del oxígeno desde la lluvia a la calcita espeleotémica, y así valorar la capacidad de esta señal para conservar información medioambiental. Se han comparado

Recibido el 1 de abril de 2014 / Aceptado el 27 de noviembre de 2014 / Publicado online el 17 de diciembre de 2014

Citation / Cómo citar este artículo: M.C. Osácar et al. (2014). Tracking the oxygen isotopic signature from the rainfall to the speleothems in Ortigosa de Cameros caves (La Rioja, Spain). Estudios Geológicos 70(2): e021. http://dx.doi.org/10.3989/egeol.41730.319.

Copyright: ( 2014 CSIC. This is an open-access article distributed under the terms of the Creative Commons Attribution-Non Commercial (by-nc) Spain 3.0 License. 


\begin{abstract}
las señales isotópicas del oxígeno de los eventos de la lluvia, el agua de goteo (muestreada trimestralmente) y la calcita espeleotémica, precipitada también durante cada trimestre. El goteo en las cuevas responde a la precipitación en invierno, primavera y verano, más estrechamente en los puntos más próximos a la superficie que en los profundos. En otoño hay un retraso entre la lluvia y el goteo, lo que sugiere que el agua permanece por un tiempo en el epikarst, antes de que se reanude el goteo después del verano. Este retraso provoca que la señal isotópica del agua de goteo (media total de $\delta^{18} \mathrm{O}=-8.39 \%$ V-SMOW) se desvíe de la señal de la lluvia (media de $\delta^{18} \mathrm{O}=-7,41 \%$ V-SMOW). Por el contrario, en invierno la señal isotópica del agua de goteo es muy semejante a la de la lluvia. La composición isotópica de la calcita espeleotémica (media total de $\delta^{18} \mathrm{O}=-6,83 \%$ V-PDB) presenta un pequeño desfase $(0,62-0,75 \%)$ respecto al valor que le correspondería por la composición isotópica del agua de goteo; esto indica que los efectos cinéticos durante la precipitación de la calcita son limitados, por lo que ésta conserva la señal de la lluvia, especialmente en invierno.
\end{abstract}

Palabras clave: señal isotópica del oxígeno; calcita espeleotémica; monitorización de cuevas; Norte de la Península Ibérica.

\section{Introduction}

Stalagmite oxygen isotope $\left(\delta^{18} \mathrm{O}\right)$ is commonly used as a proxy of external environmental conditions (Lachniet et al., 2009; McDermott, 2004) for palaeoclimate reconstructions, inasmuch as the rainfall isotopic composition is transposed to the speleothem calcite. However, the isotopic changes in the pathway from the rainfall to the speleothem are not completely understood, because of the many complex factors involved, which are related to climate, soil and vegetation, epikarst and cave environment (McDermott, 2004; Lachniet et al., 2009; Feng et al., 2014). In fact, every karst system or every cave may usually display a unique and individual isotopic response (Bradley et al., 2010).

A first approach to addressing this subject deals with the isotopic $\left(\delta^{18} \mathrm{O}\right)$ analysis of drip waters (Treble et al., 2013; Luo et al., 2014) as an intermediate step from the external climate signature to the speleothemic one. Thus, cave monitoring involving this strategy becomes a useful method to assess palaeoenvironmental interpretations derived from stalagmites (Cruz et al., 2005; Baldini et al., 2006; Mattey et al., 2008; Feng et al., 2014, Genty et al., 2014).

Previous works (Muñoz \& Sancho, 2008; Muñoz et al., 2009; Muñoz et al., 2010) have shown the potential of the Ortigosa Cave to refine the relationship between the environmental features and the speleothem chemistry. Through sampling and analyses of the isotopic composition of rainfall, drip waters and in-situ resulting precipitated calcite, we explore the transference of the isotopic signature, in order to assess the processes prevailing in the intermediate reaches (from rainfall to drip water and from drip water to calcite) in the Ortigosa Cave System (Northern Iberian Peninsula).

\section{Study area and cave features}

The study area is located in the westernmost sector of the Cameros Range (Iberian Mountain System, Northern Spain) (Fig. 1a). La Paz and La Viña Caves are located in the Encinedo Mountain (Fig. 1b) near Ortigosa de Cameros village (La Rioja). The geological framework is made up of a Paleozoic basement, a Mesozoic cover, dipping to the S-SE, and a subhorizontal sequence of Cenozoic conglomerates. The Ortigosa Cave System is developed within marine limestones of the Middle Jurassic (ITGE, 1990) and is one of the most important endokarstic features in the Iberian Range. La Viña Cave is $114 \mathrm{~m}$ long and is located at $1080 \mathrm{~m}$ above the sea level. La Paz Cave is longer $(236 \mathrm{~m})$ and it develops $20 \mathrm{~m}$ above the former (Fig. 1c). Both, La Paz and La Viña Caves, exhibit horizontal development and geometry controlled by the direction of the main regional NE-SW fault system (Fig. 1a). The karstified massif is covered by poorly developed calcareous soils (rendzina) and supports a mesophytic forest of Quercus ilex and Quercus rotundifolia.

\section{Methods and materials}

Several environmental parameters have been monitored both outside and inside the Ortigosa Cave system over a full year (autumn 2011- summer 2012). Rainfall amount was measured continuously and sampled for isotopic composition $\left(\delta^{18} \mathrm{O}\right.$ and $\left.\delta \mathrm{D}\right)$. Temperature values were obtained from the closest meteorological station of Villoslada de Cameros (Government of La Rioja: http://www.larioja.org/ npRioja/default/defaultpage.jsp?idtab=457643).

Inside the caves, dripping rate, relative humidity $(\mathrm{RH})$ and temperature were continuously recorded by means of several HOBO sensors: one drip gauge 

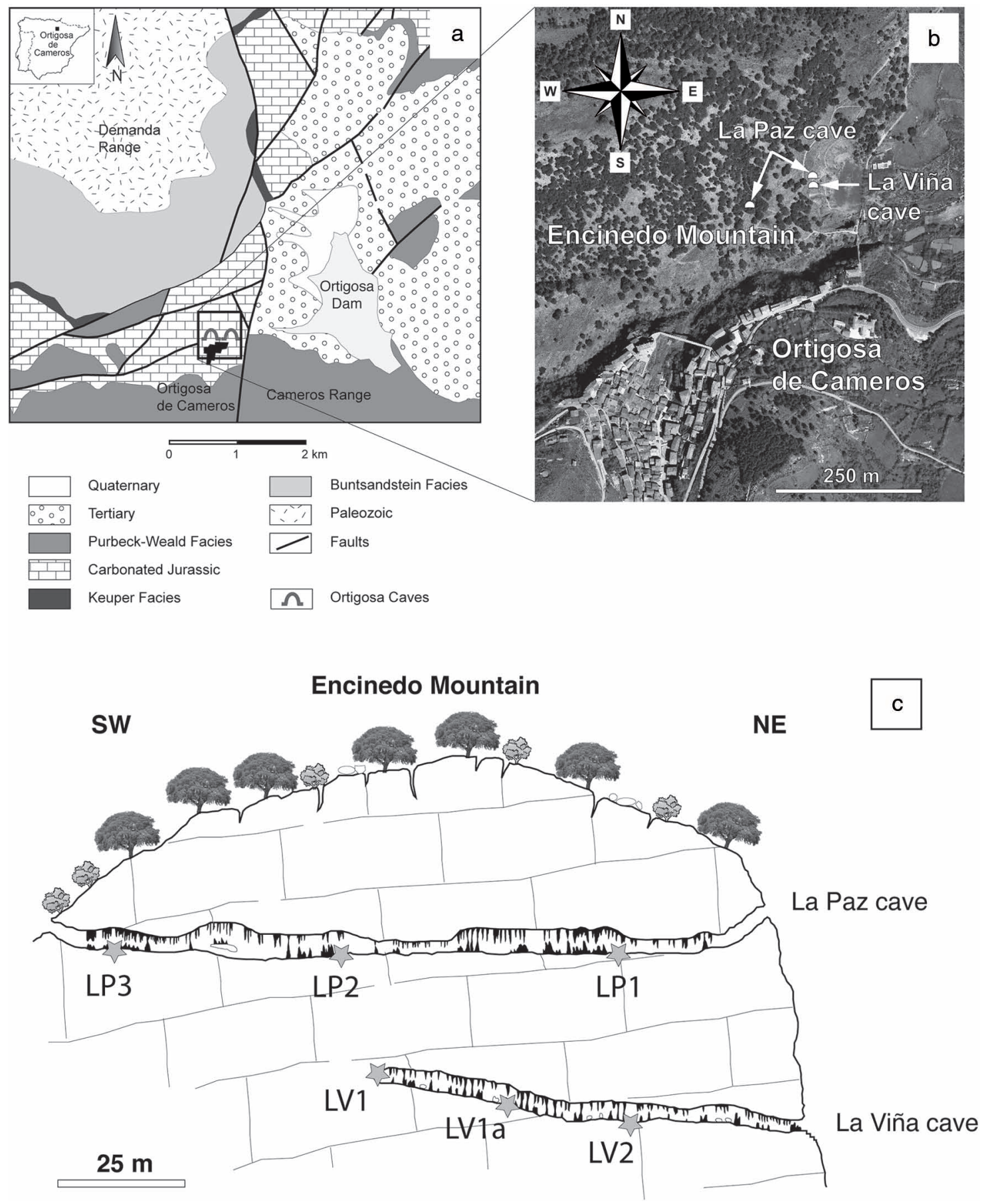

Fig. 1.- Geographic and geological setting of the Ortigosa de Cameros cave system (a). Aerial photograph with the location of the caves (La Paz Cave has two entries) (b). Scheme section of the Encinedo Mountain and location of the study sites (c).

in each cave (sites LV1 and LP2 in Fig.1c), and two sensors of temperature and $\mathrm{RH}$ in La Viña Cave and three in La Paz (sites LV1, LV2, LP1, LP2 and LP3, in Fig. 1c). Drip water was sampled manually for isotopic analysis $\left(\delta^{18} \mathrm{O}\right)$ every three months, in the middle of the corresponding season (November, March, May and August): two sites (LV1a and LV2) were sampled in La Viña Cave and three sites (LP1, LP2, and LP3) in La Paz Cave (Fig. 1c). Speleothem calcite records were obtained by precipitation on 
glass plates placed under dripping points, nearby the water sampling sites (one per dripping site), and removed every three months, at the end of the corresponding season (December, March, June and September); the precipitated calcite was analyzed for oxygen isotopic composition $\left(\delta^{18} \mathrm{O}\right)$.

Rain water isotope oxygen and hydrogen analyses were carried out at the IACT-CSIC in Granada, in a Finnigan Delta Plus XL mass spectrometer. Water samples were equilibrated with $\mathrm{CO}_{2}$ for the analysis of $\delta^{18} \mathrm{O}$ values (Epstein \& Mayeda, 1953), while the hydrogen isotopic ratios were measured on $\mathrm{H}_{2}$ produced by the reaction of $10 \mu \mathrm{L}$ of water with metallic zinc at $500{ }^{\circ} \mathrm{C}$, following the analytical method of Coleman et al. (1982). The results are expressed as $\delta^{18} \mathrm{O}$ and $\delta \mathrm{D} \%$ o $\mathrm{V}$-SMOW.

Drip water oxygen was determined at the Department of Environmental Sciences of the J. Stefan Institute in Ljubljana (Slovenia). The water samples were poisoned with a solution of $\mathrm{HgCl}_{2}$ immediately after sampling to prevent biological activity before the analysis. The results are also expressed as $\delta^{18} \mathrm{O} \%$ o V-SMOW.

Calcite oxygen isotope composition was determined by using a Thermo Finnigan MAT252 mass spectrometer coupled with a CarboKiel-II carbonate preparation device at the Scientific and Technological Centers form the University of Barcelona. The results are reported as $\delta^{18} \mathrm{O} \% \mathrm{~V}$-PDB.

\section{Results}

\section{Environmental conditions}

Regional climate is of continental Mediterranean type, with a mean annual temperature of $9{ }^{\circ} \mathrm{C}$ and a mean annual precipitation of $630 \mathrm{~mm}$. During the monitored time the mean temperature was of $9.93{ }^{\circ} \mathrm{C}$ and the annual precipitation of $522.48 \mathrm{~mm}$. Precipitation occurs mainly in autumn and spring, although there were some important events in July 2012 (Fig. 2).

\section{Internal parameters}

In La Viña Cave only the LV1 sensor has recorded the whole monitored time span, with a mean daily temperature of $12.17{ }^{\circ} \mathrm{C}$ and extreme values of $11.91{ }^{\circ} \mathrm{C}$ (June 29, 2012) and $12.46^{\circ} \mathrm{C}$ (August 26, 2012). The extreme values of the incomplete record

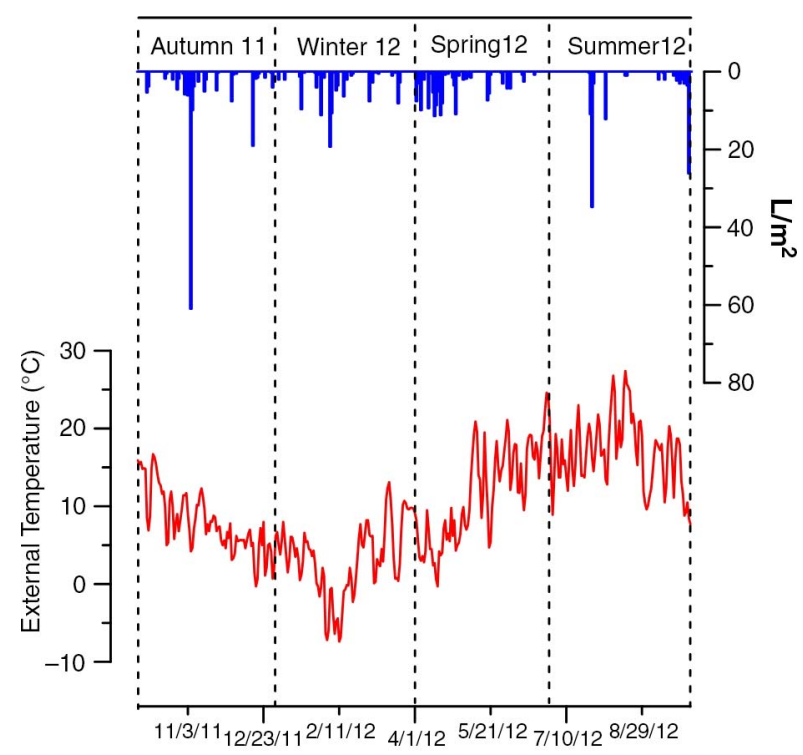

Fig. 2.- Local mean daily temperature and rainfall in La Viña and La Paz Caves during the monitored time period.

of LV2 sensor are $11.95{ }^{\circ} \mathrm{C}$ (March 28, 2012) and $13.36^{\circ} \mathrm{C}$ (August 22, 2012). The $\mathrm{RH}$ is $100 \%$, invariably, for both LV1 and LV2 sensors.

In La Paz Cave the LP2 and LP3 sensors supplied complete records through the monitored time. The mean daily temperature recorded by sensor LP2 was $11.43{ }^{\circ} \mathrm{C}$, with extreme values of $11.16^{\circ} \mathrm{C}$ (March 2, 2012) and $11.60^{\circ} \mathrm{C}$ (August 30, 2012); LP3 recorded a mean daily temperature of $10.99^{\circ} \mathrm{C}$, with extreme values of $9.29{ }^{\circ} \mathrm{C}$ (March 29, 2012) and $12.2{ }^{\circ} \mathrm{C}$ (September 22, 2012). The LP1 sensor only recorded since March 2012, with extreme values of $11.27^{\circ} \mathrm{C}$ (March 22, 2012) and $11.89{ }^{\circ} \mathrm{C}$ (September 30, 2012). The average RH values were $100 \%$ for LP2 sensor and $98.11 \%$ for LP3 sensor.

Temperature variations inside the caves are small. The main difference among sensors corresponds to LP3, which shows the widest temperature range. This fact has been explained, in a previous work (Muñoz et al., 2012), by its position, close to the surface and to one of the entrances. The seasonal changes in temperature (differences between three-month means) in LV1 and LP2, the sites where the drip rate of each cave was measured, are $0.1{ }^{\circ} \mathrm{C}$ and $0.2^{\circ} \mathrm{C}$ respectively. This is coherent with a higher thermal inertia in La Viña Cave than in La Paz Cave, related to the deeper position of La Viña Cave and the thicker rock roof above it, that slows down the heat transference from the outside (Muñoz et al, 2010). 
Other factors, mainly the visitor entry, have been observed to affect the cave temperature, mainly due to lighting and ventilation. In fact, radon and $\mathrm{CO}_{2}$ monitoring have shown that ventilation is more efficient in La Viña Cave than in La Paz Cave, in spite of the former having a thicker rock roof and only one entrance (Muñoz et al., 2012). Nevertheless, both the small variation of temperature and relative humidity inside the caves over the year, as well as the lack of asymmetric development of current erratic forms, for instance, botryoidal forms, point to a limited effect of ventilation, at least in the sampling and measurement cave areas, far enough from the entrances.

Water dripping inside the caves is irregular and responds to the local rainfall events. In summer, dripping decreases, and even ceases, in the two caves. If the drip rate records of both caves are compared with the local rainfall record (Fig. 3), it can be observed that, in general, rain events are almost immediately followed by an increase in the drip rate, except in autumn. Over this season there is a delay between the rainfall events and the resume of the dripping inside the caves, which starts in mid-October/beginning of November in La Paz/La Viña Caves. This delay is likely related to the response time of the karstic system after the summer. For the rest of the year, rainfall events are quickly reflected in the dripping in both caves, although in La Paz Cave the dripping mimics the rainfall more closely, whereas in La Viña Cave dripping rates are more moderate and even dripping continues after the rain ceases, i.e. the response to rainfall events is slower. The dripping rates do not reflect the intensity of rainfall events with the same magnitude, most likely because in some cases, during particularly intense events, rainfall water is partially lost through run-off, which reduces the infiltration into the epikarst.

The lack of water dripping record in La Viña Cave during most of the winter 2012 is due to technical problems of the sensor.

\section{Isotopic composition}

\section{Rainfall}

Isotopic composition of rainfall is plotted in Fig. 4. The $\delta^{18} \mathrm{O}$ values span from $-3.01 \% \mathrm{~V}$-SMOW to $-14.48 \%$ V-SMOW, with a mean value of $-7.41 \%$ V-SMOW, and $\delta \mathrm{D}$ spans from -21.48 to $-105.13 \%$ V-SMOW,
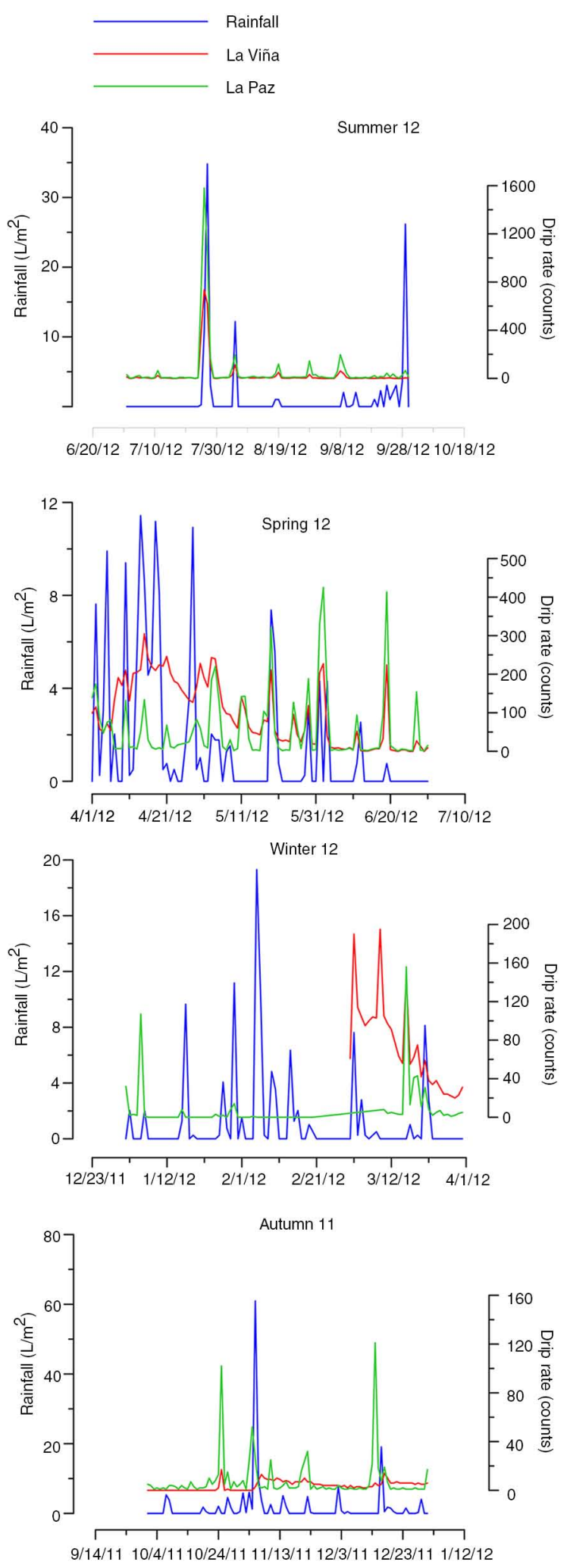

Fig. 3.- Seasonal comparison between rainfall events and drip water rates in La Viña and La Paz Caves; vertical scales are different for each season. 


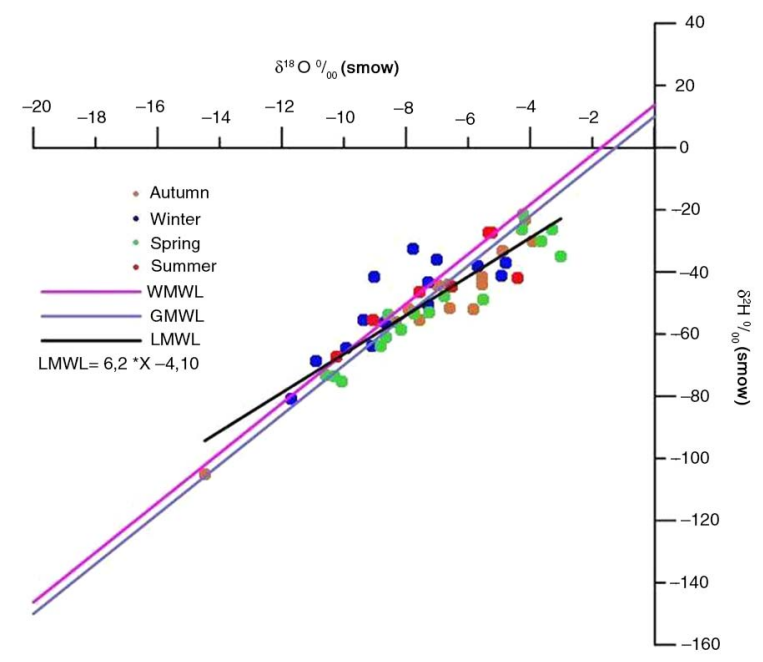

Fig. 4.- Rainfall $\delta^{18} \mathrm{O}$ and $\delta \mathrm{D}$ Ortigosa from October 2011 to September 2012; Global Meteoric Water Line, Western Mediterranean Water Line and Local Meteoric Water Line.

with a mean value of $-50.13 \%$ V-SMOW. Deuterium and oxygen analysis of rainfall plot around the Global Meteoric Water Line (GMWL) and the Western Mediterranean Meteoric Line (WMML) although with a lower slope (GMWL: $\delta \mathrm{D}=8 \times \delta^{18} \mathrm{O}+10$; WMML: $\delta \mathrm{D}=8 \times \delta^{18} \mathrm{O}+13.7$; this work: $\left.\delta \mathrm{D}=6.23 \times \delta^{18} \mathrm{O}-4.1\right)$ (Fig. 4). There are not remarkable differences among values of rainfall of different seasons, although winter values tend to be lower. Snow precipitation, more frequent in winter and spring, can be significant: the average of snow $\delta^{18} \mathrm{O}$ of the studied year is $-9.19 \%$ V-SMOW, assuming the precipitation occurs when the mean daily temperature is below $4{ }^{\circ} \mathrm{C}$. Taking into account the wind direction during the precipitation, the lowest isotopic values correspond to NNW to WNW wind directions (mean $\delta^{18} \mathrm{O}=-8.86 \%$ $\mathrm{V}-\mathrm{SMOW}$ ) and the highest to S-SSE wind directions (mean $\delta^{18} \mathrm{O}=-4.74 \% \mathrm{~V}-\mathrm{SMOW}$ ), whereas WSWSSW wind directions show intermediate values (mean $\delta^{18} \mathrm{O}=-6.94 \%$ V-SMOW). Snow precipitation occurs under NNW to WSW wind directions.

\section{Dripping water and precipitated calcite}

Average isotope composition is $\delta^{18} \mathrm{O}=-8.39 \%$ $\mathrm{V}$-SMOW in drip water, and $\delta^{18} \mathrm{O}=-6.83 \%$ V-PDB in the glass-precipitated calcite. The evolution of oxygen isotopes of both dripping water and calcite precipitated in glass plates is plotted in Fig. 5. They display parallel trends, with lower values in winter and spring than in
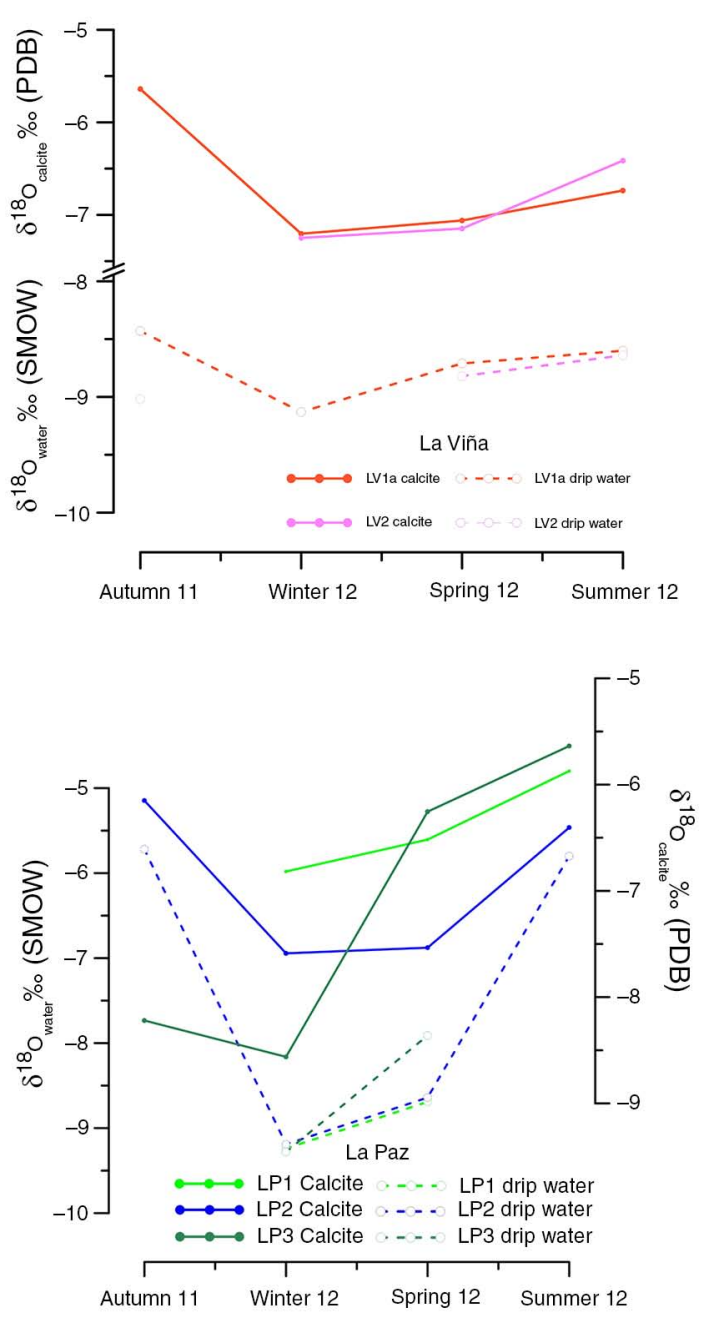

Fig. 5.- Seasonal evolution of average oxygen isotope signals of dripping water and speleothem calcite.

summer and autumn; in these seasons, displaying the highest $\delta^{18} \mathrm{O}$ values, water dripping was scarce and only one site could be sampled for water in La Paz Cave. In La Viña Cave the two measurement sites yield similar values through the monitored time, whereas in La Paz, closer to the surface, values are higher in autumn and summer and lower in winter and spring.

\section{Discussion}

\section{From rainfall to dripping}

Rainfall is the primary source for the water in the speleothemic process, and the final drip water isotopic signal will depend both on the isotopic 
composition of rainfall and on the changes that rain water suffers along the pathways through the reservoir, until it reaches the cave. Moreover, the characteristics and intensity of these transformations can vary through time and space (McDermott, 2004; Lachniet et al., 2009; Johnston et al., 2013; Feng et al., 2014).

The isotopic signal of rainfall depends very much both on the provenance of the precipitation and on the temperature. At Ortigosa location, due to the latitudinal position and other geographic factors (altitude, orography, etc.), precipitation generated by frontal depressions related to western Atlantic flows are predominant, although convective storms associated with eastern flows and cyclogenetic processes in the Mediterranean basin itself are also common, mainly in summer (Celle \& Jeanton et al., 2001). Taking into account the wind direction associated to each precipitation event, the high values recorded for rainfall coming from S-SE wind directions, that is, a likely Mediterranean origin, are significant of this influence. Besides, the influence of snow precipitation is limited, because the mean $\delta^{18} \mathrm{O}$ value of precipitation from NNW to WNW directions, excluding the snow (mean value $=-7.47 \%$ V-SMOW), is still lower than the mean $\delta^{18} \mathrm{O}$ corresponding to the S-SE directions.

Thus, the "source effect", although partially concealed by the seasonality, would be one of the main influences in the final $\delta^{18} \mathrm{O}$ values of precipitation at this location. This effect is due to the different air mass histories and temperatures of the moisture sources (Craig, 1961; Dansgaard, 1964; Rozanski et al., 1993; Araguás-Araguás et al., 2000) and would explain the seasonality of the rainfall isotopic composition represented in Fig. 6.

In the Ortigosa Cave System the relationship between drip water rates and rainfall events (Fig. 3) suggests that rainfall water enters into the cave through the epikarst with almost no delay, except in autumn; therefore this is the only season in which significant changes in water from the rain to the dripping can be expected. Figure 7 shows the comparison between rainfall and drip water oxygen signal, taking the weighted mean of the rain events prior to the water sampling moment. In autumn, the isotopic composition of drip water is much heavier than the rain water, especially in $\mathrm{La}$

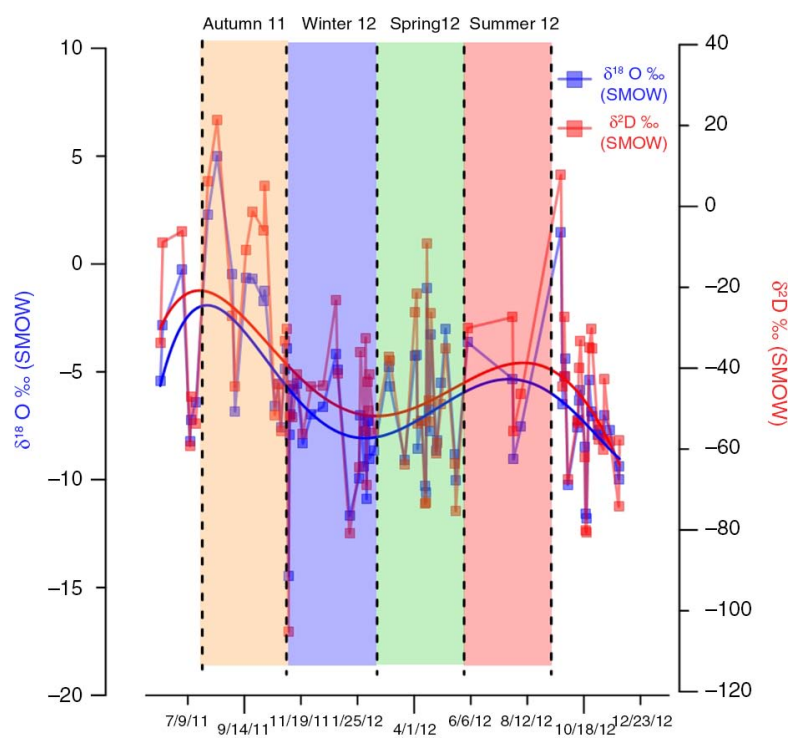

Fig. 6.- Evolution of rainfall events and rainfall isotopic composition $\left(\delta^{18} \mathrm{O}\right.$ and $\left.\delta^{2} \mathrm{D}\right)$ during the monitored time period. The curve lines, obtained by a polynomial fitting, show the variation along the three-month periods linked to drip water and calcite sampling.

Paz Cave, in agreement with the time delay shown between rainfall and water dripping resuming after summer; this residence time allows a certain degree of isotopic change in water, by depletion in the lighter isotope (Feng et al., 2014; Genty et al., 2014). Depletion in the light isotope can be absolute, due to evaporation in the epikarst, or relative,

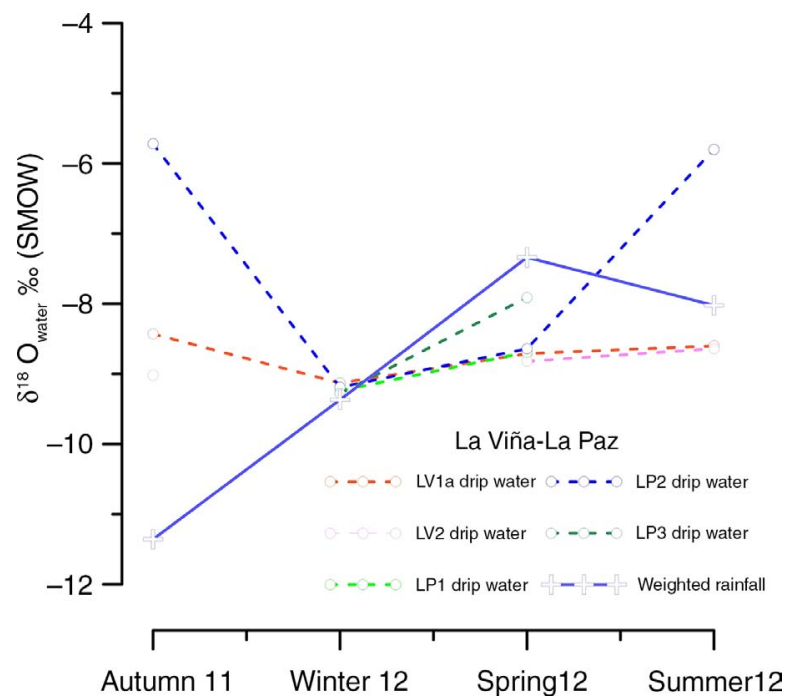

Fig. 7.- Comparison between rainfall and drip water oxygen isotopic composition. Rainfall values correspond to the weighted mean of the rain events prior to the water sampling of the season. 
due to the input of the heavier isotope of the limestone by dissolution (Fairchild et al., 2006).

In other seasons the isotopic signal in drip water is closer to the rain water. In winter the isotopic signal in drip water is the same as the rain water, in spring drip water is slightly lighter than rain water, and in summer is lighter in La Viña Cave and heavier in La Paz. Partial evaporation of rain water, prior to the analysis, can result in drip water lighter than the rainfall water from which it derives. In addition, the lost of the specific rainfall event which produced the sampled drip water can also yield drip water lighter than the measured rainfall water. In spring, most likely, some of the rainfall events contributing to the analysed drip water were missing. In summer, although all rainfall events related with the sampling drip water were analysed, drip water $\delta^{18} \mathrm{O}$ increases while rainfall $\delta^{18} \mathrm{O}$ decreases, with respect to the previous spring values; in La Paz Cave $\delta^{18} \mathrm{O}$ of drip water is even heavier than $\delta^{18} \mathrm{O}$ of rainfall. As rainfall in summer is scarce, water probably has remained in the epikarst for longer, before dripping, for which a certain degree of depletion in the lighter isotope can be expected.

\section{From dripping water to speleothem calcite}

In both caves $\mathrm{RH}$ is close to $100 \%$ during the whole year; besides, as it has been stated above, the measurement and sampling sites are placed in areas where ventilation is weak, therefore, its effects on the isotopic signature of speleothem calcite should be limited. Therefore, the isotopic composition of calcite depends only on the water isotopic composition and on the temperature dependant fractionation (Feng et al., 2014). In the Ortigosa Cave System the temperature oscillations through the year are very small (Muñoz et al., 2010), for which the primary control is the water isotopic composition. Thus, the environmental information is transferred to the speleothem calcite, provided that the isotopic fractionation process is reasonably free of kinetic effects.

To assess the oxygen isotopic fractionation in the speleothem calcite precipitation, its oxygen isotopic composition has been compared with the predicted values estimated from the formula by Tremaine et al. (2011):

$1000 \ln \alpha=\left(16.1 \times 10^{3} \times \mathrm{T}^{-1}\right)-24.6$ where $\alpha$ is the fractionation factor, which is estimated from the measured temperatures; then, the predicted $\delta^{18} \mathrm{O}$ of calcite was calculated from the formula:

$$
\alpha^{\prime}=\left(\delta^{18} \mathrm{O}_{\text {calcite VSMOw }}+1000\right) /\left(\delta^{18} \mathrm{O}_{\text {water VSMOw }}+1000\right)
$$

The results show that measured calcite $\delta^{18} \mathrm{O}$ is, in general, less negative than the predicted $\delta^{18} \mathrm{O}$; the only exceptions are two cases in La Paz Cave. The differences between measured and predicted values are in the range of the systematic offset values recorded in other monitored caves with the same or similar formula (Tremaine et al., 2011 and references therein). The average offset is smaller in La Viña Cave $(0.62 \%$ ) than in La Paz Cave $(0.75 \%$ ), in agreement with the stronger covariation between the isotopic signals of drip water and calcite in La Viña $(r=0.81, n=6)$ than in La Paz $(\mathrm{r}=0.58, \mathrm{n}=7)$. In this situation the kinetic effects in calcite precipitation are limited (Feng et al., 2014) and it is commonly assumed that some environmental information is retained by the calcite (Tremaine et al., 2011, Wackerbath et al., 2010).

This is confirmed by the parallel evolution of oxygen isotopic composition of drip water and calcite through the monitored period (Fig. 5). Nevertheless, in La Viña Cave, at the two sites (LV1a and LV2), values of both drip water and calcite are almost constant, whereas in La Paz Cave site LP2 and, especially, site LP3, which is the closest to the surface, shows larger variations, with heavier values in autumn and summer. Site LP3 in La Paz can be reached even by water coming from low intensity rainfall events or partially evaporated water in summer. On the contrary, La Viña Cave, which is below La Paz, shows more homogeneous values and only the delayed isotopic effect observed in autumn and, partially, the depletion in the light isotope in summer water can be recognized. Thus, discarded the effect of ventilation on the isotopic composition of speleothem calcite, the differences in calcite can be explained by the composition of the drip water, which, in turn, is related with the relative depth of the drip points and the water residence time in the epikarst, above the caves. Differences in oxygen isotopic composition with depth in caves have been also recorded in other caves (Genty et al., 2014), which are also linked to the different composition of the water that reaches the different cave levels. 
In both caves, winter shows the lightest values of calcite $\delta^{18} \mathrm{O}$, which agrees with both the drip water and the rain water, and it probably displays the best matching between drip water and precipitation, as it has been observed in other caves (Feng et al., 2014).

\section{Conclusions}

Several preliminary conclusions may arise from this one-year study (autumn 2011- summer 2012), tracking the oxygen isotopic signature from the rainfall to the speleothems in the Ortigosa Cave System:

1. Dripping inside the Ortigosa Cave System follows rainfall almost immediately in winter, spring and summer. In autumn there is a delay between rainfall and water dripping. This delay corresponds to the time needed for the surface water to reach the cave after summer, when the epikarst loses most of its water content.

2. Except in autumn, the water dripping keeps the rainfall isotopic signal with little or no change, especially in winter. In autumn the drip water isotopic signal is heavier than the corresponding rainfall; this divergence is likely connected to this season delay between rainfall and water dripping.

3. Differences in both drip water and calcite $\delta^{18} \mathrm{O}$ have been observed between the two caves, related to their depth.

4. Kinetic effects in calcite precipitation are small enough for the isotopic signal of calcite to retain the rainfall information, especially in winter, when the lowest values of $\delta^{18} \mathrm{O}$ are measured, in agreement with the rain water composition.

These preliminary conclusions cannot be considered definitive but only as a working hypothesis for subsequent research.

\section{ACKNOWLEDGEMENTS}

This study was mainly funded by the CGL2009-10455/ BTE research project of the Ministry of Science and Innovation and FEDER and the Análisis de Cuencas Sedimentarias Continentales, Geotransfer, PaleoQ y Gemorfología y Cambio Global research groups of the Aragón Government. We are most grateful to $\mathrm{M}^{\mathrm{a}}$ Angeles, Sara y Juan for their invaluable help. We also thank to the Ortigosa de Cameros town hall for the cave access. The Government of La Rioja is acknowledged by the meteorological data from Villoslada de Cameros station. We are indebted to the referees for their valuable comments.

\section{References}

Araguás-Araguás, L.; Froehlich, K. \& Rozanski, K. (2000). Deuterium and oxygen-18 isotope composition of precipitation and atmospheric moisture. Hydrological Processes, 14: 1341-1355. http://dx.doi. org/10.1002/1099-1085(20000615)14:8<1341::AIDHYP983>3.0.CO;2-Z.

Baldini, J.U.L.; McDermott, F. \& Fairchild, I.J. (2006). Spatial variability in cave drip water hydrochemistry: Implications for stalagmite paleoclimate records. Chemical Geology, 235: 390-404. http://dx.doi.org/ 10.1016/j.chemgeo.2006.08.005.

Bradley, C.; Baker, A.; Jex, C.N. \& Leng, M.J. (2010). Hydrological uncertainties in the modelling of cave drip-water $\delta 180$ and the implications for stalagmite palaeoclimate reconstructions. Quaternary Science Reviews, 29: 2201-2214. http://dx.doi.org/10.1016/ j.quascirev.2010.05.017.

Celle-Jeanton, H.; Travi, Y. \& Blavoux, B. (2001). Isotopic typology of the precipitation in the Western Mediterranean Region at three different time scales. Geophysical Research Letters, 28: 1215-1218. http:// dx.doi.org/10.1029/2000GL012407.

Coleman, M.L.; Shepard, T.J.; Durham, J.J.; Rouse, J.E. \& Moore, G.R. (1982). Reduction of water with zinc for hydrogen isotope analysis. Analytical Chemistry, 54: 993-995. http://dx.doi.org/10.1021/ac00243a035.

Craig, H. (1961). Isotopic Variations in Meteoric Waters. Science, 133: 1702-1703. http://dx.doi.org/10.1126/ science.133.3465.1702.

Cruz, F.W.Jr.; Karmanna, I.; Viana, O.Jr.; Burnsb, S.J.; Ferraric, J.A.; Vuilleb, M.; Siald, A.N. \&. Moreira, M.Z. (2005). Stable isotope study of cave percolation waters in subtropical Brazil: Implications for paleoclimate inferences from speleothems. Chemical Geology, 220: 245-262. http://dx.doi.org/10.1016/ j.chemgeo.2005.04.001.

Dansgaard, W. (1964). Stable isotopes in precipitation. Tellus, 16: 4 36-468. http://dx.doi.org/10.1111/ j.2153-3490.1964.tb00181.X

Epstein, S. \& Mayeda, T. (1953). Variation of $\mathrm{O}^{18}$ content of waters from natural sources. Geochimica et Cosmochimica Acta, 4: 213-224. http://dx.doi.org/ 10.1016/0016-7037(53)90051-9.

Fairchild, I.J.; Smith,C.L.; Baker, A.; Fuller, L.; Spötl, C.; Mattey, D.; McDermott, F. \& E.I.M.F. (2006). Modification and preservation of environmental signals in speleothems. Earth-Science Reviews, 75: 105-153. http://dx.doi.org/10.1016/j.earscirev.2005.08.003.

Feng, W.; Casteel, R.C.; Banner, J.L. \& Heinze-Fry, A. (2014). Oxygen isotope variations in rainfall, dripwater and speleothem calcite from a well-ventilated cave in Texas, USA: Assessing a new speleothem temperature proxy. Geochimica et Cosmochimica Acta, 127: 233-250. http://dx.doi.org/10.1016/j. gca.2013.11.039. 
Genty, D.; Labuhn, I.; Hoffmann, G.; Danis, P.A.; Mestre, O.; Bourges, F.; Wainer, K.; Massault, M.; Exter, S.V.; Régnier, E.; Orengo, Ph.; Falourd, S. \& Minster, B. (2014). Rainfall and cave water isotopic relationships in two South-France sites. Geochimica et Cosmochimica Acta, 131: 323-343. http://dx.doi.org/10.1016/j. gca.2014.01.043.

ITGE. (1990). Mapa geológico de España. Escala 1:50.000. $2^{\text {a }}$ Serie (241) Anguiano, Madrid, Servicio de Publicaciones del Ministerio de Industria y Energía.

Johnston, V.E.; Borsato, A.; Spötl, C.; Frisia, S. \& Miorandi, R. (2013). Stable isotopes in caves over altitudinal gradients: fractionation behaviour and inferences for speleothem sensitivity to climate change. Climate of the Past, 9: 99-118. http://dx.doi.org/10.5194/ cp-9-99-2013.

Lachniet, M.S. (2009). Climatic and environmental controls on speleothem oxygen-isotope values. Quaternary Science Reviews, 28: 412-432. http://dx.doi. org/10.1016/j.quascirev.2008.10.021.

Luo, W.; Wang, S.; Zeng, G.; Zhu, X. \& Liu, W. (2014). Daily response of drip water isotopes to precipitation in Liangfeng Cave, Guizhou Province, SW China. Quaternary International, 349: 153-158. http:// http://dx.doi.org/10.1016/j.quaint.2014.01.043.

Mattey, D.; Lowry, D.; Duffet, J.; Fisher, R.; Hodge, E. \& Frisia, S. (2008). A 53 year seasonally resolved oxygen and carbon isotope record from a modern Gibraltar speleothem: Reconstructed drip water and relationship to local precipitation. Earth and Planetary Science Letters, 269: 80-95. http://dx.doi.org/ 10.1016/j.epsl.2008.01.051.

Muñoz, A. \& Sancho, C. (2008). Monitorización climática de las cuevas de Ortigosa de Cameros (La Rioja): aplicación a la interpretación del registro climático de los espeleotemas holocenos. Zubía, 20: 21-36.

Muñoz, A.; Sen, A.K.; Sancho, C. \& Genty, D. (2009). Wavelet analysis of Late Holocene stalagmite records from Ortigosa caves in Northern Spain. Journal of Cave and Karst Studies, 71: 63-72.

Muñoz, A.; Osácar, M.C.; Sancho, C. \& Moreno, A. (2010). Dinámica espeleotémica actual en las Cuevas de Ortigosa de Cameros (La Rioja). In: Cuevas: Patrimonio, Naturaleza, Cultura y Turismo (J.J. Durán \& F. Carrasco, eds.). Asociación de Cuevas Turísticas Españolas, Madrid, 371-382.

Muñoz, A.; Osácar, M.C.; Sancho, C.; Moreno, A.; Bartolomé, M.; Muñoz, A.; Quindós, L.; Fuente, I.; Sainz, C.; Quindós, J.; Gutiérrez Villoslada, J.L. \& Quindós, L.S. (2012). Estudio de la ventilación en las cuevas de Ortigosa de Cameros (La Rioja) mediante la monitorización de la concentración de $\mathrm{CO} 2$ y radón. In: Las cuevas turísticas como activos económicos: conservación e innovación (J.J. Durán \& P.A Robledo eds.). Asociación de Cuevas Turísticas Españolas, Madrid, 349-357.

McDermott, F. (2004). Palaeo-climate reconstruction from stable isotope variations in speleothems: a review. Quaternary Science Reviews, 23: 901-918. http://dx.doi.org/10.1016/j.quascirev.2003.06.021.

Rozanski, K.; Araguás-Araguás, L. \& Gonfiantini, R. (1993). Isotopic Patterns in Modern Global Precipitation. In: Climate Change in Continental Isotopic Records (Swart, P.K.; Lohmann, K.C.; Mckenzie, J. \& Savin, S., eds.). American Geophysical Union, 1-36. http://dx.doi.org/10.1029/GM078p0001.

Treble, P.C.; Bradley, C.; Wood, A.; Baker, A.; Jex, C.N.; Fairchild, I.J.; Gagan, M.K.; Cowley, J. \& Azcurra, C. (2013). An isotopic and modelling study of flow paths and storage in Quaternary calcarenite, SW Australia: implications for speleothempaleoclimate records. Quaternary Science Reviews, 64: 90-103. http://dx.doi.org/10.1016/j.quascirev.2012.12.015.

Tremaine, D.M.; Froelich, P.N. \& Wang, Y. (2011). Speleothem calcite farmed in situ: Modern calibration of $\mathrm{d} 18 \mathrm{O}$ and $\mathrm{d} 13 \mathrm{C}$ paleoclimate proxies in a continuously monitored natural cave system. Geochimica et Cosmochimica Acta, 75: 4929-4950. http://dx.doi.org/10.1016/j.gca.2011.06.005.

Wackerbarth, A.; Scholz, D.; Fohlmeister, J. \& Mangini, A. (2010). Modelling the $\delta 180$ value of cave drip water and speleothem calcite. Earth and Planetary Science Letters, 299: 387-397. http://dx.doi.org/ 10.1016/j.eps1.2010.09.019. 